\title{
Examining of the Exam Anxiety of 12th Grade Students Doing and Not Doing Sports in High Schools in Düzce
}

\author{
Emre Turegun ${ }^{1, *} \&$ Alpay Alev ${ }^{2}$ \\ ${ }^{1}$ Faculty of Sports Sciences, Düzce University, Turkey \\ ${ }^{2}$ Institute of Graduate Studies, Sakarya University of Applied Sciences, Turkey \\ *Correspondence: Faculty of Sports Sciences, Department of Coaching Education, Düzce University, 81620 \\ Yörük/Düzce, Merkez/Düzce, Turkey. E-mail: emreturegun@duzce.edu.tr
}

Received: April 29, 2021

doi:10.5430/wje.v11n4p45

\author{
Accepted: June 25, $2021 \quad$ Online Published: August 18, 2021 \\ URL: https://doi.org/10.5430/wje.v11n4p45
}

\begin{abstract}
In this work, it was intended to investigate the exam anxiety of 12th grade students doing and not doing sports in high schools in Düzce. Exams might be a compelling process that creates excitement and stress. All student experiences the impacts of anxiety in different manners during the exam period. Experiencing a level of anxiety affects exam performance, and this reveals exam anxiety as a problem. In this study, it is going to be examined whether exam anxiety distinct among 12th grade students who do sports and those do not. A total of 400 students including 200 who do sports and 200 who do not were applied to the "Test Anxiety Inventory". SPSS 21 was used for statistical analysis of the data. In this research, exam anxiety levels of 12th grade students who do sports ad who do not in high schools in Düzce were analyzed and interpreted according to different variables. In consequence of the analysis performed in terms of variables such as doing sports, gender, sportive experiences; it was concluded that the anxiety level of the female students who have been doing sports for 3-4 years is higher compared to the male students do not sports and have been doing sports for 5 years or more.
\end{abstract}

Keywords: sports, high school, anxiety, ANOVA, Scheffe test

\section{Introduction}

Human being is in a learning process during the all of his/her life. All the works that individuals learned and experienced forms the knowledge. However, the learnings we experienced in our lives constitute our performance. In other words, it is the way in which a person activates his experiences with his mind, emotion and behavior in the right time and situation. When a person can activate the full potential, the best performance comes out. Yet, it intermittently becomes challenging to display the actual potential as a performance because it is affected by internal and external factors (Çakmak, 2007). Testing is the most common method to show the best that students can do and to measure and evaluate their success. Exams are convoluted with education and part of a whole. Even though education and examination are under consideration to be inseparable, this system induces some problems for students. One of them is anxiety. Anxiety is the dread, agitation, and disquieting mood that people experience in certain periods (Baltaş, 2002). The anxiety is handled under two headings according to Speibelger (1972). Anxiety that causes stress and distress related to the situation of the person depending on the process is "state anxiety". And with the disappearance of these, situation-related anxiety disappears. However, constant anxiety (perpetual anxiety) accompanies the person throughout his/her life and manifests itself more in some situations and spreads throughout his life (Baltaş, 2017).

Sensations those arise and develop out of the control of individuals cause by anxiety and act together with negative situations. Not being successful within insufficiency, even if he or she works in exams, the student cannot remember his/her knowledge. Nonetheless, he or she is also doing wrong. The thought that these negative situations that they experience, and feel that it will continue is settled in the students' subconscious. And it induces him to doubt about the exam (Maviş and Saygın, 2004). Exams for students begin in primary school years and continue for a long time. Yet, thoughts such as competition and future, family expectations create negative effects on students (Leta, 2001). Lately manifesting itself, the exam anxiety is more frequent especially in individuals who are preparing for the 
university entrance exam.

The importance and demand given to universities are gradually increasing with the change and development of social and economic events in our country. Students to reach this level and get academic education at the university must compete with thousands of people and be successful (Yıldırım and Ergene, 2003). Such that all the efforts of teachers and parents are focused on the success of the students and achieving higher grades. The exam anxiety increases because of the expectation of families to get better undergraduate education and having better living opportunities (social and financial) in their future lives. The students experience the effects of anxiety while they are trying to achieve all their success under these expectations. And the life begins to turn into a race (Burkovik, 2009). Due to the characteristics of their age, 12th grade students are struggling to gain their own identity and to prove themselves, they also experience anxiety because they struggle with thoughts about making decisions about their future to get an education that attracts their attention and matches their abilities. The exams, which are repeated every year in our country called previously Transition to Higher Education Examination and Undergraduate Placement Exams and changed as Basic Proficiency Test and Field Proficiency Test have the characteristics of stress, anxiety, and fear for hundreds of thousands of students (Günay et al., 2008; Soylu, 2002). Exams that concern students and people in that community and student achievements depend on multiple factors (Şahin et al., 2006). Still, this situation is reduced by doing sports. A lot of examples of this opinion can be seen in some studies. Students who socialize and spend their energy with sports unavoidably tend to try to apply this disciplinary examination system and set their goals and acting for success (Gündüz, 2015).

The students of a high school are grouped into two for a study performed by Hui (2020). One of these groups is covering the students doing sports frequently on a unique category. The other covers the students doing sports occasionally on various categories. The three problems are detected through the research. First one is the length of the exercise period; others are the insufficiency on the athletic enthusiasm and less scientific sports. The last problem was arising from the lack of attention, scientific guidance and effective supervision.

This paper is aimed to investigate individual or team sports participant high school students' perceived social anxiety levels according to their sports branch, the weekly number and period of doing sports, the aim for doing sports and gender. As a result, it is seen that professional individual sports participants had higher perceived social avoidance and distress for general and new situations. Also, male individual sports participants reported a higher fear of negative evaluation than females.

It is very important in this sense that examining the reasons that cause exam anxiety on 12th grade students. In our country, various level of anxiety can be detected among the twelfth grade students at the end of the spring semester since the university entrance examination is seen as the most important and its decisive influence.

In this study performed, curiosity arouses whether certain characteristics of the students (whether they do sports or not, social relations, different reasons related to family and educational process) influence anxiety or not. To this respect, examining whether there is a difference between the students who do sports activities and do not do sports activities, this study aims to scale and interpret the anxiety of 12th grade students who are preparing for the university entrance exam, to determine their anxiety, to see the differences in terms of anxiety situations, and to determine the factor(s) that causes anxiety. The objective is to identify the effects of the duration of different variables. It is expected that the results of this research draw a road map for the students, their families and educational system of the country.

\section{Methodology}

\subsection{Goal of the Research}

The Test Anxiety Inventory (TAI) was developed by Spielberger (1972) and its validity, reliability and adaptation to Turkish were made by Öner (1990). Descriptive and confirmatory factor analyses were made, and it was determined that it contains two dimensions, "worry" and "emotionality". TAI contains 20 items. The scores measure the general or total test anxiety level, the scores formed by the delusion sub-dimension measure the level of test anxiety delusion, and the scores formed by the affective sub-dimension measure the level of test anxiety affectivity. The Cronbach Alpha $(\alpha)$ internal consistency coefficient range is 93 to 94 . "Emotional" sub-dimension is $\alpha=.84$, "Worry" sub-dimension is $\alpha=.83$ (Kayapınar, 2006). It was aimed to investigate the exam anxiety level of 12th grade students who do sports and do not sports in high schools in Düzce.

This study is a quantitative study based on data collection using a scanning model. A questionnaire suitable for the research question was used in the research. In the schools determined in Düzce province (Düzce Borsa Vocational 
and Technical Anatolian High School, Düzce Science High School and Düzce Adnan Menderes Trade Vocational High School), before the collection of the survey data, the managers of the schools were interviewed, and the practice was carried out in the classes on the specified dates. 400 volunteer students, 200 of whom do sports and 200 who do not, participated in the research. The classes were visited on the specified dates, the explanations were made, and the surveys were filled with the participation of the students on a voluntary basis.

\subsection{Sample and Data Collection}

After the survey was created, permissions were obtained from the school managements where the application was to be carried out before it was implemented. Then the questionnaires were distributed to the students. After the survey application was completed, the data were analyzed.

\subsection{Analyzing of Data}

SPSS 21.0 program was used in the analysis of the data obtained. The data were analyzed and presented in appropriate titles and tables in line with the objectives. In the research, arithmetic mean, standard deviation, standard error, Shapiro-Wilk test, kurtosis and skewness test, independent group t-test, one-way analysis of variance (ANOVA), Scheffe test and correlation analysis test methods were used.

\section{Findings and Results}

This section contains statistical information about the data collected from students. TAI scores of 12th grade students in Düzce province are presented in Table 1.

Table 1. Descriptive Statistics of the Test Anxiety Inventory Scale

\begin{tabular}{|c|c|c|c|c|c|c|c|c|c|c|c|c|c|}
\hline \multirow[t]{2}{*}{$\mathbf{t}$} & \multirow[t]{2}{*}{$\mathbf{N}$} & \multirow[t]{2}{*}{ Range } & \multirow[t]{2}{*}{ Mean } & \multirow{2}{*}{$\begin{array}{l}\text { Min. } \\
\text { Value }\end{array}$} & \multirow{2}{*}{$\begin{array}{l}\text { Max. } \\
\text { Value }\end{array}$} & \multirow[t]{2}{*}{$\mathbf{S}$} & \multirow[t]{2}{*}{$\mathbf{S h}_{\mathbf{x}}$} & \multicolumn{2}{|c|}{$\begin{array}{c}\text { Shapiro-Wi } \\
\text { lk }\end{array}$} & \multicolumn{2}{|c|}{ Kurtosis } & \multicolumn{2}{|c|}{ Skewness } \\
\hline & & & & & & & & $\mathbf{Z}$ & $\mathbf{P}$ & value & $\mathbf{S h}_{\mathbf{x}}$ & value & $\mathbf{S h}_{\mathbf{x}}$ \\
\hline TAI-Total & 400 & $20-80$ & 41.21 & 22 & 73 & 9.53 & .24 & .985 & .000 & -.555 & .243 & .193 & .122 \\
\hline TAI-W & 400 & $8-32$ & 17.20 & 8 & 29 & 4.34 & .24 & .986 & .001 & -.431 & .243 & .140 & .122 \\
\hline TAI-E & 400 & $12-48$ & 24.01 & 13 & 44 & 6.13 & .24 & .971 & .000 & -.570 & .243 & .397 & .122 \\
\hline
\end{tabular}

As shown in Table 1, the test anxiety inventory total score (TAI-T) of the students participating in the research can be between 20 and 80, and the mean of the scale is 41.21. Test Anxiety Inventory Worry (TAI-W) sub-dimension score can be between 8 and 32, and the mean is 17.20. Test Anxiety Inventory Emotionality (TAI-E) sub-dimension score can be between 12 and 48 and the mean score is 24.01 . Based on the findings, it can be said that the students participated in the scale items prepared to determine the test anxiety levels at a medium level and that their test anxiety levels were classified as medium level. In addition, because of the Shapiro-Wilk test, it was determined TAI scores distribution did not conform to normal distribution $(\mathrm{z}=.985 ; \mathrm{p}<.05)$. However, according to the results of the normality test, it is seen that the skewness and kurtosis values are in the range of \pm 1.5 . Skewness and kurtosis values are in the range of \pm 1.5 is an acceptable condition for normality (Tabachnick \& Fidell, 2013). Based on this point, it is accepted that the distribution has a normal distribution.

To determine the existence of a significant difference between the TAI score means of the students and the gender variable, "t-test" was performed, and the test results are given in Table 2.

Table 2. Independent t-test Results According to TAI Scores and Gender Variable

\begin{tabular}{|c|c|c|c|c|c|c|c|c|}
\hline & \multirow{2}{*}{ Gender } & \multirow{2}{*}{$\mathbf{N}$} & \multirow{2}{*}{ Mean } & \multirow{2}{*}{$\mathbf{S}$} & \multirow{2}{*}{$\mathbf{S h}_{\mathbf{x}}$} & \multicolumn{3}{|c|}{ t-Test } \\
\hline & & & & & & $\mathbf{t}$ & df & p \\
\hline \multirow[t]{2}{*}{ TAI-Total } & Female & 208 & 42.51 & 9.89 & .68 & \multirow{2}{*}{2.873} & \multirow{2}{*}{398} & \multirow{2}{*}{$.004 *$} \\
\hline & Male & 192 & 39.79 & 8.94 & .64 & & & \\
\hline \multirow{2}{*}{ TAI-W } & Female & 208 & 17.87 & 4.36 & .30 & \multirow{2}{*}{3.248} & \multirow{2}{*}{398} & \multirow{2}{*}{$.001 *$} \\
\hline & Male & 192 & 16.47 & 4.22 & .30 & & & \\
\hline \multirow{2}{*}{ TAI-E } & Female & 208 & 24.64 & 6.39 & .44 & \multirow{2}{*}{2.163} & \multirow{2}{*}{398} & \multirow{2}{*}{$.031 *$} \\
\hline & Male & 192 & 23.32 & 5.76 & .41 & & & \\
\hline
\end{tabular}


As in Table 2, a statistically significant difference was found between the TAI total score means of the students and the gender variable $(\mathrm{t}=2.873 ; \mathrm{p}<.05)$. This situation reveals that test anxiety of female students is higher than male students $($ Mean $=42.51)$. The same situation is valid in both sub-dimensions of the scale.

To determine the existence of a significant difference between the TAI score means of the students and the variable of doing sports, a "t-test" was used, and the test results are given in Table 3.

Table 3. Independent T-Test Results According to TAI Scores and Doing Sports Variable

\begin{tabular}{|c|c|c|c|c|c|c|c|c|}
\hline & \multirow{2}{*}{ Group } & \multirow{2}{*}{$\mathbf{N}$} & \multirow{2}{*}{ Mean } & \multirow{2}{*}{$\mathbf{S}$} & \multirow{2}{*}{$\mathbf{S h}_{\mathbf{x}}$} & \multicolumn{3}{|c|}{ t-Test } \\
\hline & & & & & & $\mathbf{t}$ & df & p \\
\hline \multirow[t]{2}{*}{ TAI-Total } & Doing & 200 & 43.97 & 9.31 & .65 & \multirow{2}{*}{6.052} & \multirow{2}{*}{398} & \multirow{2}{*}{$.000 *$} \\
\hline & Not Doing & 200 & 38.44 & 8.95 & .63 & & & \\
\hline \multirow{2}{*}{ TAI-W } & Doing & 200 & 18.05 & 4.40 & .31 & \multirow{2}{*}{3.983} & \multirow{2}{*}{398} & \multirow{2}{*}{$.000 *$} \\
\hline & Not Doing & 200 & 16.35 & 4.12 & .29 & & & \\
\hline \multirow{2}{*}{ TAI-E } & Doing & 200 & 25.92 & 5.98 & .42 & \multirow{2}{*}{6.567} & \multirow{2}{*}{398} & \multirow{2}{*}{$.000 *$} \\
\hline & Not Doing & 200 & 22.09 & 5.67 & .40 & & & \\
\hline
\end{tabular}

According to Table 3, a statistically significant difference was found between the TAI total score means of the students and the variable of doing sports $(\mathrm{t}=6.052 ; \mathrm{p}<.05)$. This situation reveals that students who do sports have higher test anxiety than students who do not $($ Mean $=43.97)$. The same situation is valid in both sub-dimensions of the scale.

An "ANOVA test" was used to determine the existence of a significant difference between the TAI score means of the students and the duration of doing sports and the results are given in Table 4.

Table 4. ANOVA Test Results According to TAI Scores and Duration of Doing Sports Variable

\begin{tabular}{|c|c|c|c|c|c|c|c|c|c|c|}
\hline & \multicolumn{4}{|c|}{ Mean and S.S Value } & \multicolumn{6}{|c|}{ ANOVA Results } \\
\hline & Group & $\mathbf{N}$ & Mean & $\mathbf{S}$ & & KT & Sd & KO & $\mathbf{F}$ & $\mathbf{p}$ \\
\hline \multirow{2}{*}{ TAI-Total } & $1-2$ & 89 & 43.47 & 9.18 & $\begin{array}{c}\text { between } \\
\text { group }\end{array}$ & 677.89 & 2 & 338.94 & \multirow{3}{*}{4.022} & \multirow{3}{*}{$.019 *$} \\
\hline & $3-4$ & 71 & 46.17 & 8.35 & $\begin{array}{l}\text { within } \\
\text { group }\end{array}$ & 16599.9 & 197 & 84.26 & & \\
\hline \multirow{4}{*}{ TAI-W } & $5+$ & 40 & 41.18 & 10.49 & Total & 17277.8 & 199 & & & \\
\hline & $1-2$ & 89 & 18.09 & 4.42 & $\begin{array}{c}\text { between } \\
\text { group }\end{array}$ & 113.05 & 2 & 56.52 & \multirow{3}{*}{2.966} & \multirow{3}{*}{.054} \\
\hline & $3-4$ & 71 & 18.77 & 4.07 & $\begin{array}{l}\text { within } \\
\text { group }\end{array}$ & 3754.45 & 197 & 19.05 & & \\
\hline & $5+$ & 40 & 16.68 & 4.72 & Total & 3867.50 & 199 & & & \\
\hline \multirow{3}{*}{ TAI-E } & $1-2$ & 89 & 25.38 & 5.95 & $\begin{array}{c}\text { between } \\
\text { group }\end{array}$ & 260.75 & 2 & 130.37 & \multirow{3}{*}{3.736} & \multirow{3}{*}{$.026 *$} \\
\hline & $3-4$ & 71 & 27.39 & 5.43 & $\begin{array}{l}\text { within } \\
\text { group }\end{array}$ & 6873.96 & 197 & 34.89 & & \\
\hline & $5+$ & 40 & 24.50 & 6.58 & Total & 7134.72 & 199 & & & \\
\hline
\end{tabular}

As it can be seen in Table 4, a statistically significant difference was found between the TAI total score means of the students and the duration of doing sports variable $[\mathrm{F}(2-197)=4.022 ; \mathrm{p}<.05]$. After this process, "Post-Hoc" analysis techniques were used to determine the source of the difference. To decide which "Post-Hoc" technique to use, first, the "Levene's test" was used to test the hypothesis whether the variances of the distributions are homogeneous or not. Variances are homogeneous ( $\mathrm{LF}=2.787 ; .064)$. It is preferred to use the commonly used "Scheffe's technique" here, and the analysis results are presented in Table 5 below. 
Table 5. Scheffe Test Results According to TAI Total Scores and Duration of Doing Sports Variable

\begin{tabular}{cccccc}
\hline & Group(i) & Group $(\mathbf{j})$ & OF $(\mathbf{i}-\mathbf{j})$ & $\mathbf{S h}_{\mathbf{x}}$ & $\mathbf{p}$ \\
\hline \multirow{6}{*}{ Scheffe } & $3-4$ years & -2.697 & 1.461 & .184 \\
& & $5+$ & 2.297 & 1.747 & .423 \\
& \multirow{3}{*}{ 3-4 years } & $1-2$ years & 2.697 & 1.461 & .184 \\
& \multirow{3}{*}{ 5+ years } & $5+$ & $\mathbf{4 . 9 9 4 *}$ & 1.815 & $\mathbf{. 0 2 4}$ \\
& & $1-2$ & -2.297 & 1.747 & .423 \\
& $3-4$ & $\mathbf{- 4 . 9 9 4 *}$ & 1.815 & $\mathbf{. 0 2 4}$ \\
\hline
\end{tabular}

According to Table 5, the difference between the TAI total score means and the duration of doing sports variable occurred between the 3-4 years group and the 5 years and above group. This situation was found to be a significant difference in favor of the 3-4-year group $(\mathrm{p}<.05)$. This situation reveals that students who have been doing sports for 3-4 years have higher anxiety levels than students who have been doing sports for 5 years or more.

In Table 4, a statistically significant difference was found between the TAI-E sub-dimension mean scores and the duration of doing sports variable $[\mathrm{F}(2-197)=3.736 ; \mathrm{p}<.05]$. After this process, "Post-Hoc" analysis techniques were used to determine the source of the difference. To decide which "Post-Hoc" technique to use, first, the hypothesis of whether the variances of the distributions are homogeneous was tested with the "Levene's test" and it was determined that the variances were homogeneous ( $\mathrm{LF}=1.406 ; .248)$. It is preferred to use "Scheffe's method", which is widely used here, and the analysis results are presented in Table 6 below.

Table 6. Scheffe Test Results According to TAI -E Total Scores and Duration of Doing Sports Variable

\begin{tabular}{|c|c|c|c|c|c|}
\hline & Group(i) & Group (j) & OF (i-j) & $\mathbf{S h}_{\mathbf{x}}$ & p \\
\hline \multirow[t]{6}{*}{ Scheffe } & $1-2$ years & 3-4 years & -2.012 & .940 & .104 \\
\hline & & $5+$ years & .882 & 1.124 & .736 \\
\hline & 3-4 years & 1-2 years & 2.012 & .940 & .104 \\
\hline & & $5+$ years & $2.894 *$ & 1.168 & .049 \\
\hline & $5+$ years & 1-2 years & -.882 & 1.124 & .736 \\
\hline & & $3-4$ years & $-2.894^{*}$ & 1.168 & .049 \\
\hline
\end{tabular}

According to Table 6, the difference between the TAI-E sub-dimension mean score and the duration of doing sports variable was found to be a significant difference between the 3-4 years group and the 5 years and above group in favor of the 3-4 years group. This situation reveals that students who have been doing sports for 3-4 years have higher anxiety levels than students who have been doing sports for 5 years or more.

\section{Discussion}

In this study, test anxiety levels of 12th grade students who do sports and do not do sports in high schools in Düzce were analyzed and interpreted according to different variables. As a result of the research, it was concluded that the anxiety levels of female students were higher than male students. In their studies, Kisa (1996) and Gençdoğan (2006) found that the anxiety levels of 12th grade girls were higher than that of male students. Çakmak (2007) found in his study that generally girls mean of anxiety were higher than boys, and stated that there was no semantic similarity between female and male students' state trait anxiety levels.

In the study of Günay et al. (2008), the state and trait anxiety scores of female students were found to be significantly higher than male students, and this phenomenon is attributed to the fact that girls are more emotional. Also in the study of Tunc and Akandere (2020), it is decided that the well-being scores of females who doing sports activities are higher than the non-sporting females. In many studies on students, anxiety and depression levels were found to be higher in female students than male students (Bilge and Pektaş, 2004; Kısa, 1996; Genç, 2013; Özbaş et al., 2012; Dolence et al., 2015). In almost of the research that is about university tests, female students were more anxious than male students (Şahin et al, 2006; Karadeniz, 2005; Balc1, 1997; Baltaş, 1993).

Güler and Çakır (2013) found in their study on senior high school students that female students' emotionality scores were higher than males. There was no significant difference between the worry scores. These findings support the 
fact that girls are more prone to certain psychological problems (such as anxiety disorders, depression tendencies) caused by their physiological structures compared to boys. These studies support our research.

Besides, according to the result of the study performed by Caz et al. (2019) the test anxiety is not affecting the gender and department variables. There are also studies in the literature showing that men have higher anxiety levels. In the study of Erözkan (2004), there was no high difference in test anxiety emotionality scores in terms of genders, while a high degree of difference was found in test anxiety delusional scores, and the worry scores of boys were found to be higher than girls. Baştürk (2007) found in his study that test anxiety scores of male students were higher than that of girls. In the study done by Üstün and Yapıcı (2019) for the individual sports activities, it is seen that males have higher fear of negative grading than females.

As a result of the research, it was concluded that students who do sports have higher anxiety levels than students who do not. In a study, it is stated that participation in physical activity had no effect on test anxiety and there was no statistically significant difference (Cleveland, 2017). In a similar study, it was seen that there is no significant difference between the state and trait anxiety of the students $(\mathrm{N}=160)$ who do sports and those who do not (Özgül, 2003).

When the literature is examined, it has been found that there are studies in which students who do sports have lower anxiety levels and higher academic achievements than those who do not. In the study performed by Öznur (2014) it is concluded that those having high levels of physical activity have lower anxiety levels than those with low physical activity levels. In their study of Kalemoğlu and İmamoğlu (2010) on the school success of students it is determined that their school success is affected positively thanks to sports. In another study, Pollatschek and O'Hagan (1989) it is stated that students who participate in regular sports activities create positive results in their motor skills, emotional development, and academic success. In the study of Johnston et al. (2020) on improving sleep quality it is proved that the individuals concerning physical activities have more advantages than the others. The research done by Hui (2019) summarizes the main problems existing in trying to suppress the anxiety by doing sports at personal and educational levels. It is advised that the educational establishments should actively direct their students to do sports, to provide physical education and offer psychological intervention to those have psychological problems.

Fox et al. (2010) examined how middle and high school students' participation in physical activity and sports team activities affect their academic achievement. As a result of the research, it was determined that participation in any physical activity has positive effects on academic success. Considering the assumption that students in leisure time activity will have lower mean scores on test, trait, and state anxiety scores, Erdoğan (2012) found that participation in leisure activities was lower, whereas in situational anxiety, the means were found to be lower. It is concluded that the state anxiety of the students in the leisure time activity was higher. Although no significant results were obtained in the mean trait anxiety data, a significant difference was found between state anxiety and test anxiety. The final assumption, in the studies on the effects of participation in sports activities and artistic activities on anxiety situations, has been found to be lower than the mean test and trait anxiety participation in sports activities compared to those who do not participate. State anxiety was higher in students who participated in sports activities compared to those who did not.

\section{Conclusion and Implication}

In our country, since the preparation for university entrance procedure is so long, many of problems are detected as enthusiasm, anxiety, nervousness, emotional falls, insomnia and loss in job eagerness. In this period, the examination performances can be affected negatively. The families and the school managements have to support the students to overcome these problems with the knowledge of their emotional status.

The results of this study imply that the families and the school managements must direct and motivate the students to sport activities for improvement of their mental skills to have higher grades in the examinations. The social anxiety and the personal well-being demand of 12 th grade students will be affected positively by sport activities.

In this context;

- The students must be directed to sport activities before the exam period is started.

- The positive effects of sport can be employed to overcome the exam fear and anxiety by beginning sport in as early as ages.

- It must be emphasized that the wining desire is less important than the fun and relaxation.

- The anxiety levels of females can be decreased by directing them to sport activities more. To achieve this, 
the educational establishments must supply more facilities for them.

- The studying discipline can be managed by sportive education.

It is not forgotten that the sport has competition and racing. The sportive affairs of the students coming from the sport competition sense must be cured by teachers or coaches or psychological support.

\section{Recommendations for Future Studies}

The study group of the research includes only 12th grade students from three high schools in Düzce, and the research was designed only according to the quantitative method. In other studies, to be carried out, qualitative data collection methods can be used, or the sample group can be changed. Thus, it can be determined whether different environmental and social factors influence test anxiety, if any, to what extent. The research can be repeated with different types of classes.

\section{References}

Balc1, S. (1997). The Relationship Between High School Students' Locus of Control and Exam Anxiety, (Unpublished master thesis). Gazi University, Ankara, Türkiye.

Baltaş, A. (1993). Outstanding success in learning and exams without being overwhelmed by stress (8th bask1). Remzi Kitabevi: İstanbul.

Baltaş, A. (1998). Outstanding achievement in learning and exams. Remzi Kitabevi.

Baltaş, A., \& Baltaş, Z. (1997). Stress and ways to cope. Remzi Kitapevi.

Baştürk, R. (2007). Examination of exam anxiety levels of teacher candidates preparing for the public personnel selection exam. Firat Üniversitesi Sosyal Bilimler Dergisi, 17(2), 163-176.

Bilge, A., \& Pektas, İ. (2004). Investigation of students' socio-cultural characteristics, levels of conditional anxiety, and communication skills. Ege Üniversitesi Hemşirelik Fakültesi Dergisi, 20(1), 47-55.

Burkovik, Y. (2009). What to Anxiety About. Timaş Yayınları, İstanbul.

Caz, Ç., Çoban, O., \& Yildirim, M. (2019). The Analysis of Test Anxiety among Students at School of Physical Education and Sports in Terms of Demographic Variables. Journal of Education and Learning, 8(1), 214-219. https://doi.org/10.5539/jel.v8n1p214

Cleveland, A. (2017). Move More, Stress Less: Exploring the Relationship between Physical Activity and Test Anxiety in Undergraduate Nursing Students. Undergraduate Honors Theses, 17.

Dolenc, P. (2015). Anxiety, self-esteem and coping with stress in secondary school students in relation to involvement in organized sports. Slovenian Journal of Public Health, 54(3), 222. https://doi.org/10.1515/sjph-2015-0031

Erdoğan, M. (2012). Examination of test success and anxiety levels of 12th grade students who are preparing for the university exam with and without leisure activities (Master's thesis). İstanbul Arel Üniversitesi Sosyal Bilimler Enstitüsü).

Erözkan, A. (2004). Exam anxiety and coping behaviors of university students. Muğla Üniversitesi Sosyal Bilimler Enstitüsü Dergisi, 12, 13-38.

Fox, C. K., Barr-Anderson, D., Neumark-Sztainer, D., \& Wall, M. (2010). Physical activity and sports team participation: Associations with academic outcomes in middle school and high school students. Journal of school health, 80(1), 31-37. https://doi.org/10.1111/j.1746-1561.2009.00454.x

Gençdoğan, B. (2006). Relationships between high school students' test anxiety and submissiveness levels and social support perception. Atatürk Üniversitesi Sosyal Bilimler Enstitüsü Dergisi, 7(1), 153-164.

Güler, D., \& Çakir, G. (2013). Examining predictors of test anxiety levels among 12th grade high school students. Türk Psikolojik Danışma ve Rehberlik Dergisi, 4(39), 82-94.

Günay, O., Öncel, Ü. N., Erdoğan, Ü., Güneri, E., Tendoğan, M., Arzu, U. Ğ. U. R., \& Başaran, O. U. (2008). Factors affecting the level of status and continuous anxiety in high school final students. Sağlik Bilimleri Dergisi, 17(2), 77-85. 
Hui, J. (2020). Correlation between sports activities and anxiety states of college students. Revista Argentina de Clínica Psicológica, 29(2), 301.

Johnston, S. A., Roskowski, C., He, Z., Kong, L., \& Chen, W. (2020). Effects of team sports on anxiety, depression, perceived stress, and sleep quality in college students. Journal of American College Health, 1-7. https://doi.org/10.1080/07448481.2019.1707836

Kalemoğlu, Y., \& İmamoğlu, A. F. (2010). Parents' Views on the Effects of Sports on Primary School Students' School Achievement, 1. Uluslararası Çocuk ve Spor Kongresi/Bildiriler kitabı, Yakın Doğu Üniversitesi, Kuzey Kıbris Türk Cumhuriyeti, 432-444.

Karadeniz, E. (2005). The relationship between anxiety levels, coping methods and locus of control of senior high school students and their parents preparing for the university entrance exam. Yayınlanmamış Yüksek Lisans Tezi, Marmara Üniversitesi, Eğitim Bilimleri Enstitüsü, İstanbul.

Kayapınar, E. (2006). Examining the anxiety levels of primary school 8th grade students who are preparing for the secondary education institutions student selection and placement exam. (Afyonkarahisar İli Örneği) (Master's thesis). Afyon Kocatepe Üniversitesi, Sosyal Bilimler Enstitüsü.

Kısa, S. S. (1996). The relationship between exam anxiety and parental attitudes of senior high school students attending private teaching institutions in Izmir city center. Yayımlanmamış Yüksek Lisans Tezi, Dokuz Eylül Üniversitesi: Sosyal Bilimler Enstitüsü.

Maviş, Adil \& Saygın, Oğuz (2004). Success Guide for Those Preparing for Exams. İstanbul: Hayat Yayınc1lı.

Murat, G. E. N. Ç. (2013). Determination of exam anxiety levels of primary school students according to class and gender. Celal Bayar Üniversitesi Sosyal Bilimler Dergisi, 11(01), 85-95.

Öner, N. (1990). Test anxiety inventory handbook. İstanbul: Yükseköğretimde Rehberliği Yayma Vakfı Yayını No:1.

Özbaş, A. A., Sayın, A., \& Coşar, B. (2012). Examination of the relationship between pre-exam anxiety level and early maladaptive schema in students preparing for the university exam. Bilişsel davranış̧̧ı psikoterapi ve araştırmalar dergisi, 1(2), 81-89.

Özgül, F. (2003). State and Trait Anxiety Levels of Physical Education and Sports School Students, (Master's Thesis). Cumhuriyet Üniversitesi Sağlık Bilimleri Enstitüsü).

Pollatschek, J. L., \& O'Hagan, F. J. (1989). An investigation of the psycho-physical influences of a quality daily physical education programme. Health Education Research, 4(3), 341-350. https://doi.org/10.1093/her/4.3.341

Şahin, H., Günay, T., \& Batı, H. (2006). University entrance exam anxiety among senior high school students in Bornova, Izmir. Sürekli Tip Eğitimi Dergisi, 15(6), 107-113.

Soylu, Ö. (2002). A Comparison of Psychological Symptoms of Students Preparing for the University Exam According to the Perception of Social Support from their Families (Master's Thesis). Çukurova Üniversitesi Sosyal Bilimler Enstitüsü).

Spielberger, C. D. (1966). Theory and research on anxiety. Anxiety and behavior, 1(3), 3-20. https://doi.org/10.1016/B978-1-4832-3131-0.50006-8

Tunç, A. Ç., \& Akandere, M. (2020). Effects of Sports on Social Anxiety and Subjective Well-Being Levels of University Students. Journal of Education and Training Studies, 8(1), 14-19. https://doi.org/10.11114/jets.v8i1.4552

Üstün, Ü. D., \& Yapici, A. (2019). A Comparison of Perceived Social Anxiety among Individual and Team Sports Participant High School Students. World Journal of Education, 9(6), 1-6. https://doi.org/10.5430/wje.v9n6p1

Yildirim, İ., \& Ergene, T. (2003). Exam anxiety, submissive behaviors and social support as predictors of academic success of high school seniors. Hacettepe Üniversitesi Eğitim Fakültesi Dergisi, 25(25).

\section{Copyrights}

Copyright for this article is retained by the author(s), with first publication rights granted to the journal.

This is an open-access article distributed under the terms and conditions of the Creative Commons Attribution license (http://creativecommons.org/licenses/by/4.0/). 